\title{
Na chrbte koňa k lepšiemu fyzickému a psychickému zdraviu
}

\author{
Soňa Boriová ${ }^{1,2}$ - Robin Pěnička ${ }^{1}$ \\ 1 Ústav antropologie Př́rodovědecké fakulty Masarykovy univerzity, Kotlářská 2, 61137 Brno \\ 2 Archeologický ústav AV ČR, Brno, v. v. i., Středisko po výzkum paleolitu a paleoantropologie, Dolní Věstonice 25
}

Do redakce doručeno 10. ř́ina 2018; k publikaci přijato 5. prosince 2018

\section{ON THE HORSEBACK FOR BETTER PHYSICAL AND MENTAL HEALTH}

ABSTRACT This article deals with hippotherapy and therapeutic use of horse, its characteristics and biomechanical patterns which are crucial for this type of therapy. In the field of hippotherapy, we conducted a survey of the laic public (control group, 40 respondents) and participants of the therapy (research group, 38 respondents) using the anonymous questionnaire method. The results in the control group show good public awareness (100\% of respondents) of this type of therapy and its use. The results in the research group gave an overview of the composition of the clients (mostly patients with physiological and combined problems; $76 \%$ of the respondents) and the way patients use therapy most (mainly as a complementary type of therapy; $92 \%$ of respondents). Differences between groups were observed, for example, in information sources. In the control group, internet was the most common source of information ( $29 \%$ of respondents), while in the research group, the popularity of the use and effectiveness of therapy was spread mainly by oral administration between patients and clients ( $47 \%$ of respondents). On the other hand, similar answers in both groups were recorded regarding the health issues which can hippotherapy relieve from and efficiency and use of this therapy mainly as complementary. This fact shows that general public is well and truly informed about use and effect of hippotherapy.

KEY WORDS horse; hippotherapy; training; relationship with animals; movement; psychic

ABSTRAKT Tento článok sa venuje hipoterapii ako terapeutickému využitiu koňa, jej charakteristike a biomechanickým zákonitostiam, ktoré sú klúčové pre tento druh terapie. V oblasti hipoterapie sme pomocou dotazníkovej metódy vykonali prieskum laickej verejnosti (kontrolná skupina; 40 respondentov) a účastníkov terapie (výskumná skupina; 38 respondentov). Výsledky v kontrolnej skupine poukazujú na dobrú informovanost verejnosti (100\% respondentov) o tomto druhu terapie a jej využití. Výsledky v skupine výskumnej poskytli náhlad do zloženia klientely (najmä pacienti s problémami fyziologického a kombinovaného charakteru; 76\% respondentov) a spôsobu akým pacienti terapiu najviac využívajú (hlavne ako doplnkový typ terapie; $92 \%$ respondentov). Rozdiely medzi skupinami boli pozorované napríklad v informačných zdrojoch. V kontrolnej skupine bol najbežnejším zdrojom informácií internet ( $29 \%$ respondentov) zatial' čo v skupine výskumnej sa povedomie o využití a účinnosti terapie šíri najmä ústnym podaním medzi pacientmi a klientmi (47\% respondentov). Naopak boli vo oboch skupinách zaznamenané zhodné odpovede týkajúce sa zdravotných problémov, od ktorých hipoterapia ulavuje, efektivity a využitia terapie najmä ako doplnkovej. Tento fakt ukazuje, že široká verejnost̉ je dobre a pravdivo informovaná o použití a účinkoch hipoterapie.

KL'ÚČOVÉ SLOVÁ kôň; hipoterapia; výcvik; vztah k zvieratu; pohyb; psychika

\section{ÚVOD DO PROBLEMATIKY}

Hiporehabilitácia je jedným $\mathrm{z}$ najrozšírenejších druhov animoterapie. Má pozitívny vplyv na človeka po fyzickej a psychickej stránke. Prvé písomné zmienky o hipoterapii nachádzame už v období starovekého Grécka (Bizub - Joy Davidson 2003, 378) avšak až v dnešnej dobe pozorujeme jej najväčší rozmach. Len v Českej republike, podla České hiporehabilitační společnosti, momentálne registrujeme 8 stredísk praktickej výuky, 25 stredísk doporučenej hiporehabilitácie, 11 registrovaných prevádzkových stredísk a 10 stredísk pridružených, ktoré sa tomuto druhu terapie venujú (Česká hiporehabilitační společnost 2018). Tento typ terapie využíva koňa ako terapeuta pre liečbu alebo rehabilitáciu telesných 
a psychických ochorení. Používa sa hlavne pri ochoreniach, ktoré po odznení akútnych stavov vyžadujú d’alšie liečenie (Hollý - Hornáček 1998, 15).

Vplyv na fyzickú stránku človeka má najmä trojrozmerný pohyb koňa. Konský krok je vo svojej biomechanickej podstate velmi príbuzný ludskej chôdzi. Ide o skrížený pohybový (krokový) vzor pohybu dopredu. Na strane vykračujúcej sa predsúva panva zatial čo na opačnej strane sa predsúva rameno a dolná končatina. Tento fakt je dôležitý pri nacvičovaní chôdze pomocou hipoterapie (Hollý - Hornáček 1998, 15). Zlepšenie a pokroky vo fyzickej sfére sú individuálne. U niektorých pacientov sa prejavia skôr a intenzívnejšie, u niektorých neskôr a s menšou intenzitou (Teichmann Engel 2008, 255-257).

Vplyv na psychickú stránku človeka hrá v procese liečenia významnú rolu, najmä u chronicky chorých. Je zdrojom motivácie po dlhých, únavných liečebných procedúrach či rehabilitáciách, kedy pacient o cvičenie stráca záujem. V človeku sa prostredníctvom motivácie a interakcie so zvieratom vytvárajú pozitívne emócie, ktoré sú základom pri liečení psychických ochorení (Dušek a kol. 1992, 62; Hollý - Hornáček 1998, 18-19; Černá Rýnešová 2011, 15-16). Dôležitá je schopnost’ koňa nadviazat neverbálny kontakt s človekom. Kôň od prírody nie je vtieravý, násilne sa neponúka a týmto spôsobom podporuje aktivitu samotného pacienta. Tým, že sa pacient naučí porozumiet' pohybom a správaniu koňa bez toho, aby mu niečo hovoril, naučí sa tieto vzorce analogicky preniest' do komunikácie s lud’mi. Významným terapeutickým faktorom je pravidelná starostlivost’ o koňa. V klientovi vytvára zmysel pre užitočnost', vytrvalost', zodpovednost' a samostatnost' (Hollý - Hornáček 1998, 19).

Prax preukazuje, že pokroky vo fyzickej oblasti nastupujú omnoho skôr, avšak ich dlhodobé trvanie je podmienené dodržiavaním pravidelnosti terapie. Na rozdiel od fyzických účinkov, zmeny v psychike a správaní prichádzajú neskôr, a majú aj po ukončení rehabilitácie dlhodobé trvanie (Bizub Joy - Davidson 2003, 381).

Hiporehabilitáciu tradične delíme do troch hlavných oblastí (Hollý - Hornáček 1998; Černá Rýnešová 2011; Teichmann Engel 2009; Slovenská hippoterapeutická asociácia 2018). Oblast' hipoterapie je liečebná metóda, pri ktorej je klient, čo sa ovládania koňa týka, úplne pasívny. Ako terapeutický činitel' je využívaný prirodzený pohyb koňa. Ten slúži pre klienta ako motorický vzor a zároveň ako balančné cvičenie. Zlepšuje u klienta koordináciu, stabilitu, upravuje svalové napätie a pôsobí pozitívne na psychiku človeka. Hipoterapia sa používa hlavne $\mathrm{v}$ oblasti fyzických tažkostí, pri ochoreniach nervového systému (napr. detská mozgová obrna), pri vadách pohybového aparátu (napr. rôzne formy skoliózy) alebo periférnych poruchách pohybového systému (vrodené či poúrazové stavy). Každý klient má individuálne zostavený plán s cielom. Terapeutická jednotka trvá väčšinou 15 až 20 minút, odporúčaná dĺžka terapie je 3 až 6 mesiacov, 2 až 3 krát týždenne. Je to minimálna doba, po ktorej sa prejavuje pozitívny efekt terapie (Hollý - Hornáček 1998, 50; Černá Rýnešová 2011, 10). Ďalšími oblastami sú psychologické, pedagogické a psychoterapeutické jazdenie a športové jazdenie postihnutých, ktorým sa náš prieskum nevenuje.

Hipoterapia využíva lokomotorické impulzy emitované z chrbta koňa počas chôdze. Impulzy produkované chodiacim koňom sú spôsobené zdvihnutím zadnej končatiny do vzduchu a dopadom prednej končatiny na zem (Janura a kol. 2009). Pri jazdení kôň svojim krokom vyšle 90-110 rytmických impulzov za minútu (Tauffkirchen 2000). Šíria sa v sagitálnej, horizontálnej a frontálnej rovine (trojrozmerný pohyb). $\mathrm{U}$ pacienta vyvolávajú reakciu $\mathrm{v}$ podobe pohybu $\mathrm{v}$ bedrovom kĺbe a v podobe klesania, stúpania a ohýbania panvy dopredu a dozadu (okrem iných). Táto reakcia simuluje pohyby vyvolávané chôdzou. Pohyb na jednej strane pôsobí uvolňujúco na svalstvo a normalizuje svalový tonus. Na strane druhej zapája axiálne a autochtónne svalstvo, ktoré sa snaží prispôsobit pohybom koňa a vytvára spätnú väzbu. Pacient zlepšuje svoju rovnováhu, stabilitu a koordináciu pohybov. Postupom terapie dochádza $\mathrm{k}$ pôsobeniu vyššieho tlaku jazdca na konský chrbát (tým, že dochádza $\mathrm{k}$ uvolňovaniu svalstva $\mathrm{v}$ dôsledku získavania dôvery a skúseností s jazdou na koni) a zvýšeniu stability (centrá tlaku sa po niekolkých terapiách stabilizujú oproti prvej terapii). S týmto trendom sa pravidelne stretávame pri osvojovaní si akýchkolvek nových pohybových aktivít. $\mathrm{Na}$ začiatku existuje vyššie sprievodné napätie (v prípade hipoterapie najmä v oblasti panvy a dolných končatín) a určité fyziologické zmeny na individuálnej úrovni, ktoré sú neskôr vystriedané relaxáciou (Janura a kol. 2009). Dochádza k posilňovaniu oslabených svalov a natahovaniu skrátených svalov. Takto je kôň schopný pacientovi poskytnút živé protézy, potlačit' a preučit patologickú chôdzu človeka, odblokovat' choré dolné končatiny od zdravého trupu (Hollý - Honáček 1998, 15; Černá Rýnešová 2011, 15). Pri jazde na koni však zapájame aj všetky ostatné svalové skupiny pomocou rôznych cvikov, ako je natahovanie sa do hrivy, rotácia tela, hádzanie lopty medzi jazdcami alebo medzi jazdcom a terapeutom, dámsky sed a d’alšie (Černá Rýnešová 2011, 46). Prenos rytmického pohybu má priaznivé účinky aj na iné telesné funkcie (dýchanie, vylučovanie hormónov, látková výmena, peristaltika). Pozitívny vplyv na uvol’nenie svalstva má aj skutočnost', že telesná teplota koňa je o 1 stupeň vyššia ako u človeka (Hollý - Hornáček 1998, 14-16; Černá Rýnešová 2011, 15, 46).

K dosiahnutiu vyššie popísaných stavov sa využíva korektný sed na koni (Obr. 1) alebo chodenie do kruhu, ktorým vieme naprávat' skoliózy tým, že klienta posadíme konkavitou smerom von z kruhu (Obr. 2) (Hollý - Hornáček 1998, 22-25, 33-40).

V prieskume sme chceli zistit do akej miery je laická verejnost', ktorá bola označená v tomto prieskume ako kontrolná skupina, informovaná a oboznámená s hipoterapiou, ako sa o nej dozvedeli a čo si myslia o jej účinnosti. Výsledky sme porovnali so skupinou výskumnou, teda skupinou účastníkov terapie, aby sme zistili či je hipoterapeutická prax a skúsenosti s ňou zhodná s informáciami, ktoré sa dostávajú širokej laickej verejnosti. Vo výskumnej skupine bolo cielom zistit s akými problémami najčastejšie ludia tento typ terapie vyhladávajú, či im reálne pomáha a v akej oblasti. 


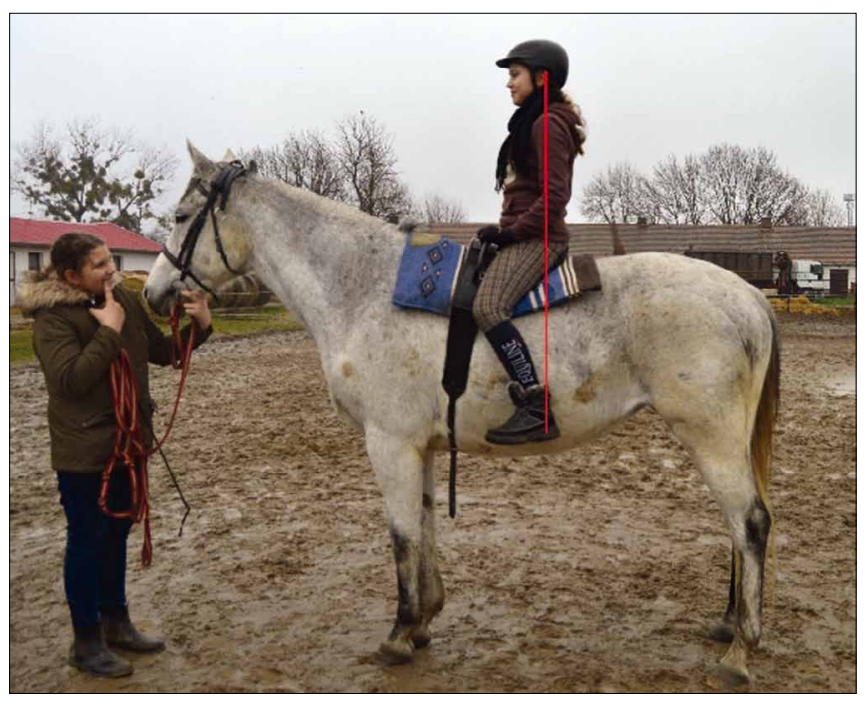

Obr. 1. Korektný sed - sed obkročmo, panva podsadená, ramená volne spustené, lakte pri tele, trup vzpriamený. Dolné končatiny sú ohnuté v bedrovom, kolennom a členkovom kĺbe, päta je najnižším bodom tela. Ucho, plece, bedrový kíb a päta sú ideálne v jednej rovine vyznačené červenou líniou (Hollý - Hornáček 1998, 33-40). Foto Soňa Boriová.

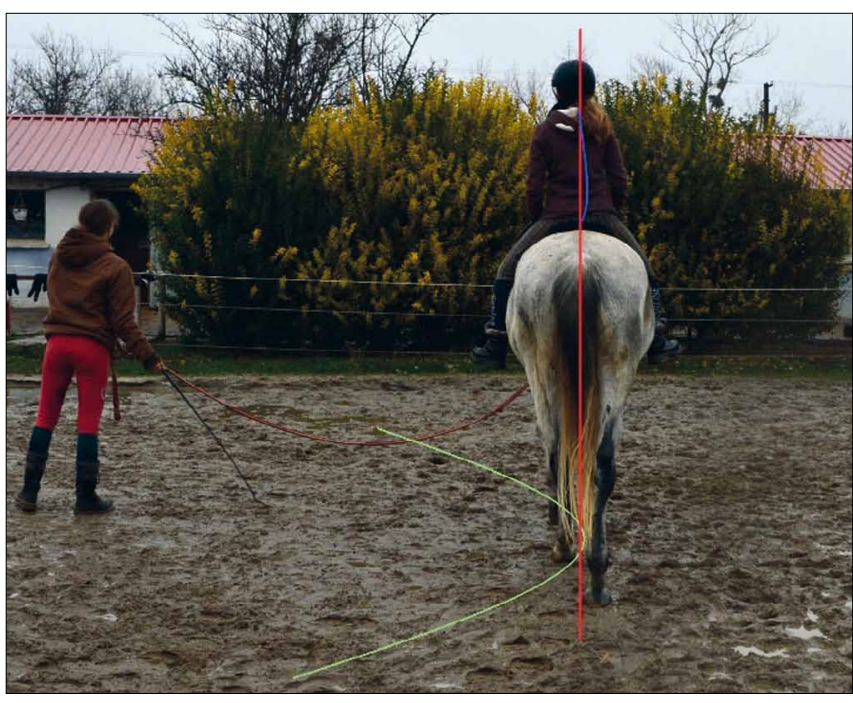

Obr. 2. Chodenie do kruhu - chrbát pacienta sa vo frontálnej rovine ohýba konvexne smerom von $\mathrm{z}$ kruhu. Ramenná a panvová rovina koňa a pacienta sú rovnobežné, to spôsobuje predsunutie vonkajšieho ramena a vnútornej strany panvy. Zelená línia značí trasu koňa, červená línia vyznačuje vertikálnu rovinu, modrá línia značí ohnutie chrbtice jazdca (Hollý - Hornáček 1998, 22-25). Foto Soňa Boriová

\begin{tabular}{|c|l|l|}
\hline Otázka č. & \multicolumn{1}{|c|}{ Znenie otázky } & \multicolumn{1}{|c|}{ Odpoved' } \\
\hline 1 & $\begin{array}{l}\text { Viete o čo sa jedná, ked’ sa hovorí o hiporehabilitácii/fyziotera- } \\
\text { peutickom jazdení? }\end{array}$ & áno / nie \\
\hline 2 & Ak áno kde/ako ste sa s týmto druhom rehabilitácie zoznámili? & $\begin{array}{l}\text { od lekára/psychológa / od známych-priatelov / } \\
\text { z internetu / z tlače-letákov / z odbornej } \\
\text { literatúry / iné }\end{array}$ \\
\hline 3 & Ak nie - čo si pod daným pojmom predstavujete? & volná \\
\hline 4 & $\begin{array}{l}\text { Viete aké problémy sa dajú liečit'/zmierňovat prostredníctvom } \\
\text { tohto druhu terapie? }\end{array}$ & volná \\
\hline 5 & Zvolili by ste v prípade potreby takýto typ terapie? & áno / nie \\
\hline 6 & Svoju volbu odôvodnite. & volná \\
\hline 7 & Myslíte si, že je takýto typ terapie účinný? & $\begin{array}{l}\text { áno / nie / čiastočne / v kombinácii s inou } \\
\text { terapiou }\end{array}$ \\
\hline 8 & Myslíte si, že je takýto druh terapie bezpečný pre pacienta? & áno / nie \\
\hline
\end{tabular}

Tab. 1. Znenie dotazníku pre kontrolnú skupinu.

\section{METODIKA A ZBER ÚDAJOV}

Pre zber dát sme zvolili dotazníkovú metódu. Použili sme polo-štruktúrovaný typ anonymného dotazníku, ktorý kombinuje otázky otvorené, s volnou odpoved’ou a otázky uzatvorené, to znamená otázky s výberom medzi pevne stanovenými odpovedami či možnostami (áno/nie/čiastočne a dalšie) (Babbie 2014, 249).

Dotazníky boli anonymné a respondenti ich vyplňali dobrovolne. Na výslednej forme dotazníkov sme spolupracovali s hiporehabilitačným centrom Epona v Brne. Presné znenie dotazníkov pre obe cielové skupiny je uvedené v tabul'ke 1 a 2 (Tab. 1; Tab. 2).
Odpovede respondentov kontrolnej aj výskumnej skupiny sme zbierali prostredníctvom osobného kontaktu, oslovovali sme respondentov prostredníctvom e-mailu (hiporehabilitačné centrá) a dotazník bol zverejnený a vol’ne prístupný on-line na internete (https://www.survio.com/survey/d/E5A6F8H6L9I5I1G8S; https://www.survio.com/survey/d/I3P0F3R2K8O6L2B2I). Pre zber dotazníkov on-line sme použili internetovú službu Survio (Survio 2016).

Prieskum prebiehal v roku 2016 (január - apríl) na území Českej a Slovenskej republiky. Nazbierané dáta sme vyhodnocovali s použitím programu Excel. Jednotlivé otázky v oboch skupinách boli vyhodnotené prostredníctvom grafov a slovným komentárom. 


\begin{tabular}{|c|l|l|}
\hline Otázka č. & \multicolumn{1}{|c|}{ Znenie otázky } & \multicolumn{1}{|c|}{ Odpoved' } \\
\hline 1 & Ako ste sa dozvedeli o hiporehabilitácii? & $\begin{array}{l}\text { od lekára/psychológa / od známych-priatelov / z interne- } \\
\text { tu / z tlače-letákov / z odbornej literatúry / iné }\end{array}$ \\
\hline 2 & $\begin{array}{l}\text { Na základe akých problémov navštevujete hiporeha- } \\
\text { bilitáciu? }\end{array}$ & $\begin{array}{l}\text { fyziologické / psychologické / kombinované / pedagogic- } \\
\text { ko - výchovné / sociálne (kontakt) / iné } \\
\text { (respondenti mali možnost' odpovede kombinovat') }\end{array}$ \\
\hline 3 & Ako dlho a ako často navštevujete tento typ terapie? & volná \\
\hline 4 & Aké máte očakávania od hiporehabilitácie? & volná \\
\hline 5 & $\begin{array}{l}\text { Vidíte rozdiely v zdravotnom stave po začatí/absol- } \\
\text { vovaní terapie? }\end{array}$ & áno / nie \\
\hline 6 & $\begin{array}{l}\text { V akej oblasti vám príde rehabilitácia najúčinnejšia/ } \\
\text { najprínosnejšia? }\end{array}$ & $\begin{array}{l}\text { hrubej motoriky (chôdza, práca s telom) / jemnej moto- } \\
\text { riky (úchop, práca s prstami) / psychickej / emocionálnej } \\
\text { / správanie / sociálna integrácia / iné }\end{array}$ \\
\hline 7 & $\begin{array}{l}\text { Navštevujete/navštevovali ste aj iný druh terapie/ } \\
\text { rehabilitácie? }\end{array}$ & áno / nie \\
\hline
\end{tabular}

Tab. 2. Znenie dotazníku pre výskumnú skupinu.

V kontrolnej skupine bol celkový počet respondentov 40, ktorí odpovedali na 8 otázok (Tab. 1).

Vo výskumnej skupine bol počet respondentov 38, ktorí odpovedali na 7 otázok (Tab. 2).

\section{VÝSLEDKY}

V kontrolnej skupine výsledky poukazujú na dobrú informovanost' laickej verejnosti (100\%). Najbežnejším informačným médiom bol $\mathrm{v}$ tomto prípade internet $(29 \%)$. Na druhom mieste boli priatelia a známi (21\%) (Graf 1). Väčšina respondentov má pomerne dobrú predstavu o tom, na čo hipoterapia slúži a aký okruh ludí ju využíva. Odpovede sa vo velkej miere zhodovali. Respondenti uvádzali problémy psychického alebo emocionálneho rázu a problémy týkajúce sa pohybového aparátu. Niektorí respondenti uvádzali aj konkrétnejšie prípady ako napríklad detská mozgová obrna, spasmus, skolióza alebo úzkost'. Len 2 respondenti zo 40 opýtaných nevedeli uviest' príklad. Len minimum respondentov uviedlo, že takémuto druhu terapie úplne nedôverujú, a že v prípade potreby by primárne siahli po iných liečebných procesoch (13\%) (Graf 2). Dôvodom bol vo väčšine prípadov strach $z$ koní či nedôvera voči liečebnému procesu. Respondentom $\mathrm{z}$ kontrolnej skupiny prišla hipoterapia i sama o sebe (50\%) ale aj v kombinácii s inými metódami účinná (32\%) (Graf 3). Ako bezpečnú hodnotilo terapiu až 97\% respondentov (Graf 4).

Výsledky výskumnej skupiny poskytli orientačný náhlad na zloženie klientely. Informácie a odporúčania terapie sa šírili najmä ústnym podaním v rámci tejto komunity (47\%). Druhým najčastejším zdrojom boli samotní ošetrujúci lekári či iní zdravotní pracovníci (Graf 5). Väčšina klientov navštevuje hipoterapiu a rehabilitačné hodiny s kombinovanými problémami (40\%) a s problémami fyziologického charakteru
(36\%) (Graf 6). Zlepšenie, ktoré referovalo 95\% respondentov (Graf 7), sledujeme hlavne v oblasti hrubej motoriky (40\%). Výraznú pozitívnu zmenu klienti zaznamenali aj v psychickej (19\% respondentov) a emocionálnej oblasti (15\%). Nasleduje zlepšenie správania (11\%), zlepšená sociálna integrácia (8\%) a na koniec zlepšenie $\mathrm{v}$ jemných motorických úkonoch (7\%) (Graf 8). Klienti, ktorí zatial' zmenu nezaznamenali (5\% respondentov), svoju odpoved' odôvodnili nepravidelným alebo krátkym dochádzaním a využívaním hipoterapie. Až 92\% respondentov uviedlo, že využívajú aj dalšie druhy terapií ako napríklad Vojtovu metódu, Bobath koncept, ergoterapiu, canisterapiu a iné (Graf 9).

\section{DISKUSIA}

Porovnanie výsledkov v oboch skupinách ukázalo, že laická verejnost' je dobre a pravdivo informovaná o tom, akým spôsobom sa táto terapia využíva. Dokazuje to zhoda odpovedí na otázku číslo 4 v kontrolnej skupine s odpoved’ami v otázke číslo 2 vo výskumnej skupine. Naše výsledky teda nasvedčujú tomu, že verejnost' je s daným druhom terapie úplne zoznámená. Či už prostredníctvom internetu alebo ústneho podania priatelov, ktorí zdielajú výsledky pôsobenia hiporehabilitácie so svojím okolím (Graf 1 a Graf 5). Respondenti v kontrolnej skupine správne predpokladali účinnost hipoterapie $\mathrm{v}$ kombinácii s inými metódami čo nám potvrdilo vyhodnotenie siedmej otázky vo výskumnej skupine. Tu účastníci hipoterapie naozaj uvádzali až v $92 \%$ účast̉ aj na iných druhoch terapie/ rehabilitácie.

Výskum Govender a kol. (2016) dokazuje, že aj medzi terapeutmi je hipoterapia často pozitívne hodnotená a vel'ká čast'z terapeutov (89\%), ktorí hipoterapiu doposial'nevyužívali, zvažujú jej použitie v budúcnosti. Dôvera v tento rehabilitačný 


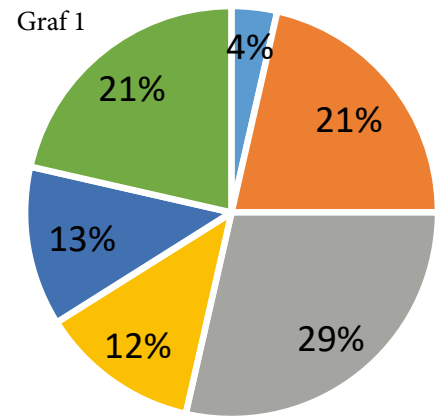

- a. Od lekára/psychológa /2

- b. Od známych/priatel'ov /12

- c. Z internetu /16

- d. Z tlače/letákov /7

- e. Z odbornej literatúry /7

- Iné /12

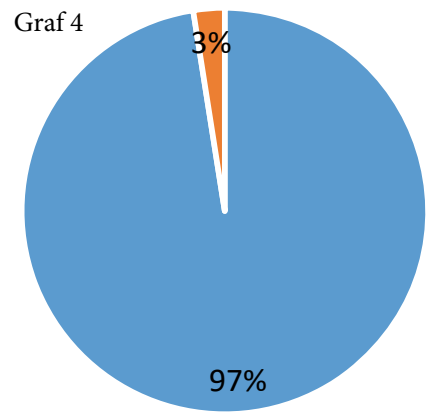

- Áno /39 피 Nie /1

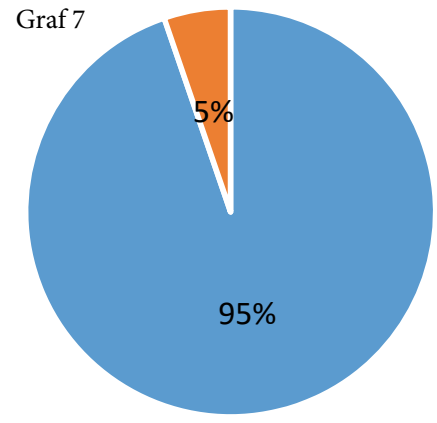

" Áno /36 - Nie /2

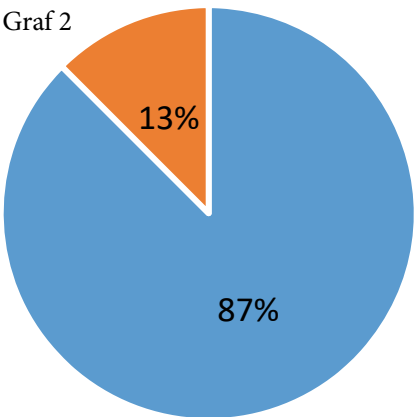

- Áno /35 Nie /5

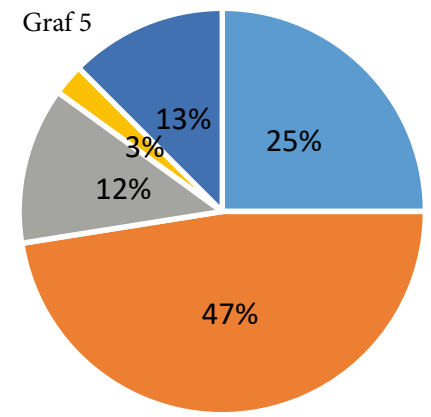

- a. Od lekára/psychológa /10

• b. Od známych/priatel'ov /19

- c. Z internetu /5

घd. Z tlače/letákov /1

- Iné /5

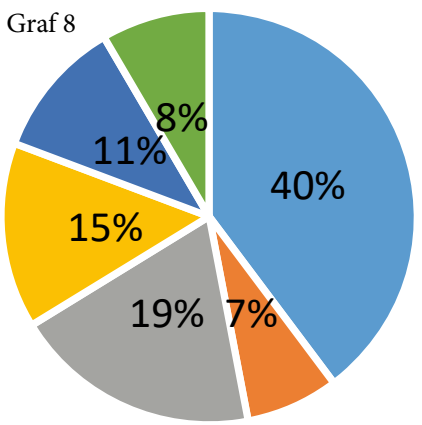

a. Hrubej motoriky

(chôdza, práca s telom) /33

b. Jemnej motoriky (úchop,

práca s prstami) / 6

c. Psychyckej /16

d. Emocinálnej /12

- e. Správanie /9

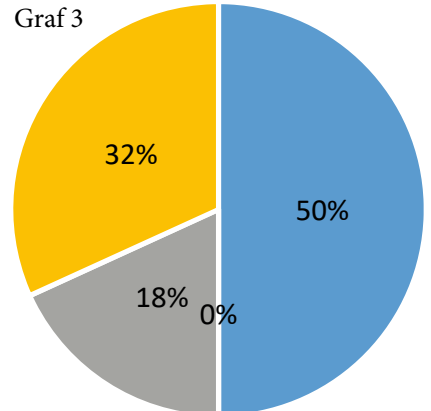

- Áno /22

- Nie /0

- Čiastočne /8

- Vkombinácii s inou terapiou /14

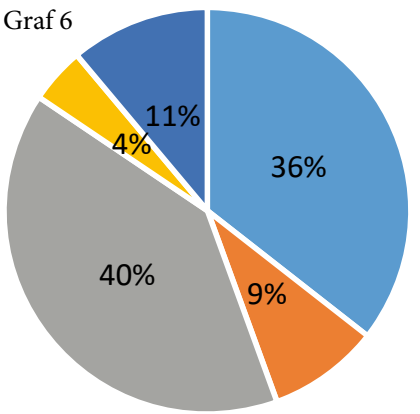

a. Fyziologické /16

- b. Psychologické /4

- c. Kombinované /18

-d. Pedagogicko - výchovné /2

- e. Sociálne (kontakt) /5

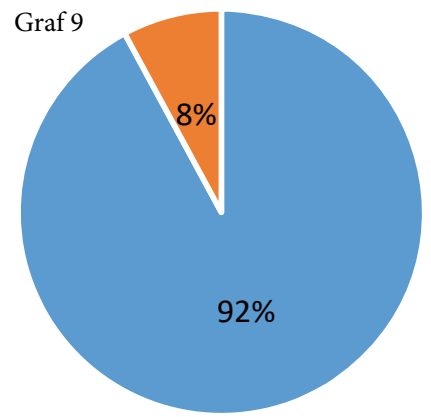

- Áno /35 Nie /3

Grafické znázornenie výsledkov odpovedí na otázky v kontrolnéj skupine: Druhá otázka - Graf 1; piata otázka - Graf 2; Siedma otázka - Graf 3; ôsma otázka - Graf 4. Grafické znázornenie výsledkov odpovedí na otázky vo výskumnej skupine: Prvá otázka - Graf 5; druhá otázka - Graf 6; piata otázka - Graf 7; šiesta otázka - Graf 8; siedma otázka - Graf 9. V legende je za lomkou uvedený počet respondentov, ktorí volili príslušnú odpoved'. 
postup medzi bežnou verejnostou $\mathrm{v}$ našom prieskume je tiež pomerne vysoká (Graf 3 ). Po bezpečnostnej stránke sa tejto terapie zdráhali len respondenti, ktorí mali vyslovene strach $\mathrm{z}$ výšok, zvierat alebo konkrétne jazdy na koni (Graf 4). Avšak práve takéto prekonanie samého seba, svojho strachu môže byt' výrazným terapeutický činitelom a mat' pozitívny vplyv nie len na klienta s diagnózou ale aj na klienta bez nej. Účinnost' hipoterapie bola potvrdená výsledkami prieskumu z výskumnej skupiny. Respondenti uvádzali spokojnost’ $\mathrm{s}$ pôsobením terapie nie len $\mathrm{v}$ najproblémovejších oblastiach daného klienta, ale tiež $\mathrm{v}$ mnohých dalších, ako napríklad komunikácia, správanie, sebapoznanie.

V našej výskumnej skupine sme sledovali najmä problémy fyziologického a kombinovaného charakteru (Graf 6). Respondenti s týmito tažkost’ami tiež najčastejšie uvádzali dobré a zretelné pokroky práve v oblasti hrubej motoriky (Graf 8). Tento výsledok potvrdzuje aj výskum Rigby a Grandjean (2016) zameraný na všeobecné zlepšenie hrubých motorických schopností pri pravidelnom navštevovaní hipoterapie alebo výskum Hornáčka a kol. (2010), ktorý sa zaoberal pôsobením hipoterapie na posturálne a lokomočné problémy pri detskej mozgovej obrne. Navštevovanie hipoterapeutických jednotiek preukázalo zlepšenie stavu. Kedže poškodené lokomočné a posturálne funkcie obmedzujú každodenný život pacienta a bežné úkony, zlepšenie v tejto oblasti a dosiahnutie väčšej samostatnosti pre nich znamenalo zásadný pokrok.

Dobrú účinnost’ však preukazuje hipoterapia aj v oblasti, ktorá sa $\mathrm{v}$ našom prieskume neukázala (absencia detí s poruchami učenia a vývinu reči vo výskumnej skupine). Práca Szamaranszkej a Filípkovej (2012) referuje kladné výsledky pri zameraní na deti s poruchami učenia a vývinu reči. Práve zvýšenie spontánnej komunikácie a verbálneho prejavu bolo jedným z najzásadnejších pokrokov u detí. Zaujímavostou je, že táto zvýšená komunikácia spočiatku prebiehala najme medzi dietatom a koňom, až neskôr dieta vyvíjalo iniciatívnu voči terapeutickému pracovníkovi, v školskom alebo rodinnom prostredí. Tento jav potvrdila aj práca Macauley (2006) kde účastníci výskumu preukazovali zvýšenú iniciatívu komunikovat práve so psím terapeutom. Je to dôležitý dôkaz toho, že zviera v terapii pôsobí ako silný motivačný činitel.

V týchto výskumoch, takisto ako v našom prieskume účastníci navštevovali zároveň rôzne iné druhy terapií a rehabilitácií (Szamaranská - Filípková 2012; Macauley 2006). V prípade pohybových problémov využívali najčastejšie Vojtovu metódu alebo Bobath koncept, u detí s problémovou rečou to bol najčastejšie logopéd alebo psychológ. Práve tento fakt by mohol do istej miery účinky hipoterapie spochybnit' a položit’ otázku, či výsledky boli dosiahnuté práve pôsobením hipoterapie. Rozdiely medzi štúdiami môžu spôsobovat aj rozdiely $\mathrm{v}$ používaných metódach, dĺžke trvania štúdie, rozdiely v počte absolvovaných terapeutických jednotiek, rozdiely v spracovaní dát a iné. Ďalšie podrobnejšie a detailnejšie zamerané výskumy by mohli odpoved' na túto otázku objasnit'.

Väčšinou je hipoterapia využívaná ako doplnková alebo sprievodná terapia, prípadne terapia nadväzujúca po odznení akútnych stavov (Graf 9). V kombinácii s inými rehabilitačnými metódami pôsobí ako komplexný typ terapie. Prax preukázala, že okrem priaznivého pôsobenia v žiadanej oblasti má pozitívny vplyv aj na iné oblasti ako napríklad zlepšenie vztahov v rodine, rozvoj komunikatívnosti, sebapoznanie, kritické myslenie, posilnenie psychomotoriky. Tieto závery vyplývajú aj zo súhrnnej štúdie Selby a Smith-Osborne (2013), kde analyzovali 14 štúdií zameraných na účinnost’ biopsychosociálnych intervencií pomocou koňa $\mathrm{v}$ populácii $\mathrm{s}$ chronickým ochorením alebo zdravotnými problémami. To všetko sú zmeny, ktoré klasické metódy praktizované v ambulantnom prostredí privodia len tažko. Tak môže byt' hipoterapia využívaná aj ako preventívny prostriedok na udržanie optimálneho zdravia alebo jeho posilnenie $\mathrm{v}$ rôznych životných situáciách. Dnes existuje vel'ké množstvo štúdií (329 výsledkov pre heslo: hippotherapy, Web of Science, k dátumu: 30.11.2018), ktoré sa pôsobením hipoterapie zaoberajú a snažia sa ju posunút na úroveň zabehnutých medicínsky overených postupov. Príkladom môže byt aj štúdia Kubota a kol. (2006), v ktorej zistili, že jazda na koni pomáha starším pacientom trpiacim na diabetes zvyšovat mieru vstrebávania glukózy. Len malé množstvo $\mathrm{z}$ existujúcich štúdií je však plne akceptovatelné. Taktiež Pauw (2000) vo svojom článku popisuje významnú diskrepanciu medzi výsledkami a zlepšeniami, ktoré popisujú rodičia či lekári a medzi štatistickou významnostou dosiahnutých výsledkov. Ako zásadný problém vidí najmä malú vel'kost' vzorky a rozdielne meracie zariadenia v rôznych štúdiách, ktoré stažujú vzájomné zrovnávanie.

\section{ZÁVER}

V našom prieskume sme zistili, že laická verejnost' je v plnej miere $(100 \%)$ informovaná a oboznámené s terapiou a jej pôsobením. O jej účinnosti sa dozvedeli hlavne prostredníctvom internetu (29\%) a $\mathrm{z}$ ústneho podania známych a priatel’ov (21\%). Pri porovnaní s účastníkmi terapie sme zistili, že odpovede na otázky týkajúce sa spôsobu využitia sa zhodujú a teda môžeme tvrdit', že široká verejnost' má správne informácie o tomto druhu terapie. Vo výskumnej skupine výsledky ukázali, že pacienti najčastejšie navštevujú terapiu s problémami kombinovanými a fyziologickými (76\%). Tieto problémy zároveň predstavujú skupinu tažkostí, ktoré sa navštevovaním terapie signifikantne zlepšujú. Zlepšenie referovalo až 95\% respondentov výskumnej skupiny a to hlavne v oblasti hrubej motoriky (40\%). Práve hrubá motorika je dôležitá pre každodenné úkony a preto je zlepšenie $\mathrm{v}$ tejto sfére pre pacientov klúčové.

\section{POĎAKOVANIE}

Podakovanie patrí projektu Špecifického výskumu Masarykovej univerzity MUNI/A/1268/2017 za ktorého podpory mohol tento článok vzniknút'. Ďalej by som rada podakovala členkám jazdeckého klubu JK Limit za asistenciu pri obrazovej dokumentácii. $\mathrm{V}$ neposlednom rade dakujem pani 
magistre Božke Minkovej-Borgulovej z hiporehabilitačného centra HIPONY za pomoc pri hladaní účastníkov výskumu a za praktické uvedenie do hiporehabilitačnej praxe.

\section{LITERATÚRA}

Babbie, E. (2014): The practice of social research, fourteenht edition. Canada, $566 \mathrm{p}$.

Bizub, A. L. - Joy, A. - Davidson, L. (2003): „It's like being in another world“: Demonstrating the benefits of therapeutic horseback riding for individuals with psychiatric disability“. Psychiatric Rehabilitation Journal, 26(4), 377-384.

Černá Rýnešová, P. (2011): Když kúň léči duši, aneb metodika hiprehabilitace zaměřná na klienty s duševním onemocněním. Pardubice: Direkte, s.r.o, $120 \mathrm{~s}$.

Dušek, J. a kol. (1992): Chov koní v Českoslovesnku. Praha: Brázda, 173 s.

Hollý, K. - Hornáček, K. (1998): Hipoterapia liečba pomocou koňa. Bratislava: Tlačové centrum Ideálne mládežníckej aktivity, Slovenská hipoterapeutická asociácia a Zväz telesne postihnutej mládeže, $181 \mathrm{~s}$.

Govender, P. - Barlow, C. - Ballim, S. (2016): Hippotheray in occupational therapy practice. South African Journal of Occupational Therapy, 46(2), 31-36.

Hornáček, K. - Kafková, A. - Páleníková, A. (2010): Pôsobenie hipoterapie na rôzne posturálne lokomočné funkcie pri spastickej kvadruparetickej forme detskej mozgovej obrny. Lekársky obzor, 59(7-8), 282-286.

Janura, M. - Peham, Ch. - Dvorakova, T. - Elfmark, M. (2009): An assessment of the pressure distribution exerted by a rider on the back of a horse during hippotherapy. Human Movement Science, 28, 387-393.

Kubota, M. - Nagasaki, M. - Tokudome, M. - Shinomiya, Y. - Ozawa, T. - Sato, Y. (2006): Mechanical horseback riding improves insulin sensitivity in elder diabetic patients. Diabetes Research and Clinical Practice, 71, 124-130.

Macauley, B. L. (2006): Animal-assisted therapy for persons with aphasia: A pilot study. Journal of Rehabilitation Research and Development, 43(3), $357-366$.

Pauw, J. (2000): Therapeutic horseback riding studies: Problems experienced by researchers. Physiotherapy, 86(10), 523-527.

Rigby, B., R. - Grandjean, P., W. (2016): The Efficacy of Equine-Assisted Activities and Therapies on Improving Physical Function. The Journal of Alternative and Complementary Medicine, 22(1), 9-24.

Selby, A. - Smith-Osborne, A. (2013): A Systematic Review of Effectiveness of Complementary and Adjunct Therapies and Interventions Involving Equines. Health Psychology, 32(4), 418-432.

Szamaranszká, I. - Filípková, B. (2012): Nechodím na terapiu, chodím na kone alebo využitie hiporehabilitácie a pedagogicko-psychologického jazdenia pri detoch s poruchami učenia a vývinu reči. Sociálne a politické analýzy, 6(2), 79-96.

Tauffkirchen, E. (2000): Kinder-Hippotherapie. In: I. Strauss (Ed.), Hippotherapie, neurophyisiologische Behandlung mit und auf dem Pferd (107-166). Stuttgart: Hippokrates.

Teichmann Engel, B. (2008): Therapeutic riding. 1., Strategies for instruction. Part 1. Durango, $332 \mathrm{p}$.

Teichmann Engel, B. - Galloway, M. L. - Bull, M. P. (2009): The horse, the handicapped and the riding team in a therapeutic riding program: A training manual for volunteers. Durango, $226 \mathrm{p}$.

Česká hiporehabilitační společnost [online]. [cit. 2018-11-29]. Dostupné z: <http://hiporehabilitace-cr.com/provozovatele-hiporehabilitace/>

Slovenská hippoterapeutická asociácia [online]. [cit. 2018-11-29]. Dostupné z: <http://www.hipoterapia-sha.sk/sha-hipoterapia-sk/5-Odborna-zona/45-Specialne-olympiady>

Survio [online]. (C) 2012-2016 [cit. 2016-3-5]. Dostupné z: <http://www.survio.com/cs/>

\section{AUTORI}

Boriová, Soňa Mgr. ( ${ }^{\star} 1994$, Bratislava). Doktorská študentka v odbore Antropológia na MU v Brne. V súčasnosti sa venuje najmä archeozoológii a problematike tafonómie na pleistocénnom osteologickom materiály živočíšneho aj ludského pôvodu.

Kontakt: Mgr. Soňa Boriová, Ústav antropologie Přírodovědecké fakulty Masarykovy univerzity, Kotlářská 2, 61137 Brno

Středisko pro paleolit a paleoetnologii Archeologického ústavu AVČR, Brno, Dolní Věstonice 25, 691 29;

e-mail: 423795@mail.muni.cz

Pěnička, Robin RNDr., Ph.D. ( ${ }^{*} 1984$, Havírov), český antropológ. Odborný asistent Ústavu antropologie Př́rodovědecké fakulty MU. Zaoberá sa najmä archeologickou antropológiou, kostrovou antropológiou a dejinami antropologického myslenia. Vo vedecko-výskumnej činnosti sa zameriava na štúdium telesných vlastností a spôsobu života obyvatel'stva ranne stredovekej Moravy, sociokultúrne aspekty modernej konzumnej spoločnosti a problematiku ludí „na okraji“"

Kontakt: RNDr. Robin Pěnička, Ph.D. Ústav antropologie Př́rodovědecké fakulty MU, Kotlářská 2, 61137 Brno;

e-mail: robin.penicka@email.cz 